\title{
Angiogenesis Activator Inhibitor
}

National Cancer Institute

\section{Source}

National Cancer Institute. Angiogenesis Activator Inhibitor. NCI Thesaurus. Code C1971.

An angiogenesis inhibitor that acts by blocking the action of endogenous pro-angiogenic substance(s). 